\title{
Contamination of Cow Milk by Heavy Metals in Serbia
}

\author{
Ivana Davidov', Zorana Kovacevic' ${ }^{1}$ Dragica Stojanovic', Mira Pucarevic², \\ Miodrag Radinovic', Natasa Stojic² \& Mihajlo Erdeljan'
}

\begin{abstract}
Background: Dairy cows are exposed to numerous environmental hazards, such as heavy metals. Milk and dairy products could be harmful to humans when maximum tolerable amounts of heavy metals are exceeded. Analysis of heavy metals in milk is important because milk is a source of essential nutrients and is an indicator of environmental contamination. Some heavy metals are essential to maintain proper metabolic activity in living organisms, but at exceeded levels they could be toxic to living organisms. The main objective of the present study was to determine the residue levels of ten heavy metals (As, $\mathrm{Cd}, \mathrm{Co}, \mathrm{Cr}, \mathrm{Cu}, \mathrm{Fe}, \mathrm{Mn}, \mathrm{Ni}, \mathrm{Pb}$ and $\mathrm{Zn}$ ) in cow milk in Serbia.

Materials, Methods \& Results: The experiment was conducted at three farms at Vojvodina district, Serbia. Cows from all three farms were on pasture during spring and summer time. Randomly 50 cows from each farm were taken for this experiment. The cows have similar body condition score they were in their third or fourth lactation and gave approximately the same amount of milk in the previous lactation. Total 150 milk samples were collected from cows during the morning milking, in the period between April to May in 2016. All 150 milk samples were transported to laboratory as soon as possible and analyzed for the heavy metals. Heavy metals were analyzed by Inductance coupled plasma - optical emission spectrometry. Data are presented as mean values $\pm \mathrm{sd}$. Statistical analysis was done by one way repeated measures analysis of variance (ANOVA). The level of significance was set at $\mathrm{P}<0.05$. The highest average concentration in cow milk was determined for Iron $(283.9 \mathrm{mg} / \mathrm{kg}$ ), then for Zinc $(60.21 \mathrm{mg} / \mathrm{kg}$ ) and Copper $(4.404 \mathrm{mg} / \mathrm{kg})$, while the lowest concentration was for Cobalt and Lead (less than $0.005 \mathrm{mg} / \mathrm{kg}$ ).

Discussion: Bioaccumulation is one of the biggest problems with heavy metals. Heavy metals residues in milk can be very dangerous for the calves and humans as well. The existence of trace elements and heavy metals in dairy products and milk has been recorded in various countries since it is considered as one of the most dangerous aspects of food contamination. The presence of heavy metals in cow's milk may be attributed to contamination due to exposure of lactating cow to environmental pollution or consumption of contaminated feeding stuffs and water. Heavy metals after intake in cow organism distributed to all organs and glands such as udder. By that, secretory udder tissue gets intoxicated with heavy metals and after that they can be found in milk. After analyses the results in this experiment the highest average concentration of $\mathrm{Fe}$ in cow milk it might be because cows were fed with hay from pasture rich in iron between April to May. Some researchers found the amounts of $\mathrm{Cu}$ in the milk of individual varied from 0.2 to $0.8 \mathrm{mg} / \mathrm{kg}$. Contrary to this finding, in current study the average value of $\mathrm{Cu}$ in cow milk was $4.404 \mathrm{mg} / \mathrm{kg}$. It is found that the highest concentration of $\mathrm{Zn}$ in cow milk is 10.75 $\mathrm{mg} / \mathrm{kg}$, lower compare to result in current study $(60.21 \mathrm{mg} / \mathrm{kg}$ ). Arsenic (As) concentration was $0.058 \mathrm{mg} / \mathrm{kg}$, cadmium (Cd) was $0.01 \mathrm{mg} / \mathrm{kg}$, cobalt (Co) was $0.002 \mathrm{mg} / \mathrm{kg}$, chrome (Cr) was $0.018 \mathrm{mg} / \mathrm{kg}$, manganese (Mn) was $0.493 \mathrm{mg} / \mathrm{kg}$, nickel (Ni) was $0.119 \mathrm{mg} / \mathrm{kg}$ and lead $(\mathrm{Pb})$ was $0.08 \mathrm{mg} / \mathrm{kg}$ what is just above recommended values by International Dairy Federation. The results showed that most of the milk samples from the different farm contained all the studied metals with concentration higher than those recommended by International Dairy Federation and Codex for cow milk.
\end{abstract}

Keywords: heavy metals, dairy cows, milk, contamination. 


\section{INTRODUCTION}

Milk is a source of essential nutrients and is an indicator of environmental contamination. The environment has dramatically transformed for the past few years in Serbia and in the world as well. Some heavy metals such as $\mathrm{Zn}, \mathrm{Se}, \mathrm{Cu}$ and $\mathrm{Fe}$ are essential to maintain proper metabolic activity in living organisms while others such as $\mathrm{Pb}$ and $\mathrm{Cd}$ are nonessential and have no biological role $[3,17]$. However, at high concentrations, they could be toxic to living organisms [14]. The toxicities induced by excessive levels of some of these elements, such as $\mathrm{Cr}, \mathrm{Cd}$, $\mathrm{Pb}$ and $\mathrm{Hg}$ are well known [15]. Heavy metals like $\mathrm{Cd}, \mathrm{Pb}$, $\mathrm{Hg}$ and As are the major toxic metals. Their concentrations in animal organisms and their milk concentrations may increase very fast, although their excretion through milk is very low [12].

Milk is an ideal source of macroelements (Ca, $\mathrm{K}$ and $\mathrm{P}$ ) and microelemts $(\mathrm{Cu}, \mathrm{Fe}, \mathrm{Zn}, \mathrm{Se})$. Addition amounts of contaminant metals might enter milk and dairy products reaching levels that are harmful to humans [17]. Milk and dairy products become contaminated with heavy metals either through food stuff and water or through manufacturing and packaging processes [1,3]. Also, there is high consummation of milk by infants and children why determination of heavy metals residual levels is particular concern [21].

The aim of the present study was to determine the residue levels of ten heavy metals (As, Cd, Co, Cr, $\mathrm{Cu}, \mathrm{Fe}, \mathrm{Mn}$, Nickel, $\mathrm{Pb}$ and $\mathrm{Zn}$ ) in cow milk.

\section{MATERIALS AND METHODS}

\section{Animals}

The study was conducted at three dairy farms at Vojvodina district in Serbia. Study included total of 150 cows, fifty cows from each farm. Cows from all three farms were on pasture during spring and summer time. Randomly 50 cows from each farm were taken for this experiment. The cows have similar body condition score they were in their third or fourth lactation and gave approximately the same amount of milk in the previous lactation $(7000 \mathrm{~L})$.

Milk collection and measurement of heavy metals

Milk samples were collected from fifty cows in each farm during the morning milking in the period between April to May in 2016. Milk samples were taken directly into sterile screw topped bottle to avoid any potential contamination. The samples were transported to the laboratory where they were analyzed. Milk samples were separated for the purpose of measuring heavy metal concentration and further analyzed by Inductance coupled plasma - optical emission spectrometry (ICP-OES system Thermo ICAP 6,500 Duo® $)^{1}$ using the EPA $6010 \mathrm{C}$ method. The detection limit was $0.005 \mathrm{ppm}$ for all samples.

\section{Statistical analysis}

Data are presented as mean values \pm sd. Statistical analysis was done by one way repeated measures analysis of variance (ANOVA). The level of significance was set at $P<0.05$.

\section{RESULTS}

The research results show that after measurement of values/concentration of heavy metals in milk samples of dairy cows in Vojvodina the highest concentration was determined for $\mathrm{Fe}(283.9 \mathrm{mg} / \mathrm{kg})$, then $\mathrm{Zn}$ $(60.21 \mathrm{mg} / \mathrm{kg})$ and $(\mathrm{Cu} 4.404 \mathrm{mg} / \mathrm{kg})$. This is provided in Figure 1. The lowest concentration of heavy metals was determined for $\mathrm{Co}$ and $\mathrm{Pb}$ with concentration less than $0.005 \mathrm{mg} / \mathrm{kg}$ (Figure 1).

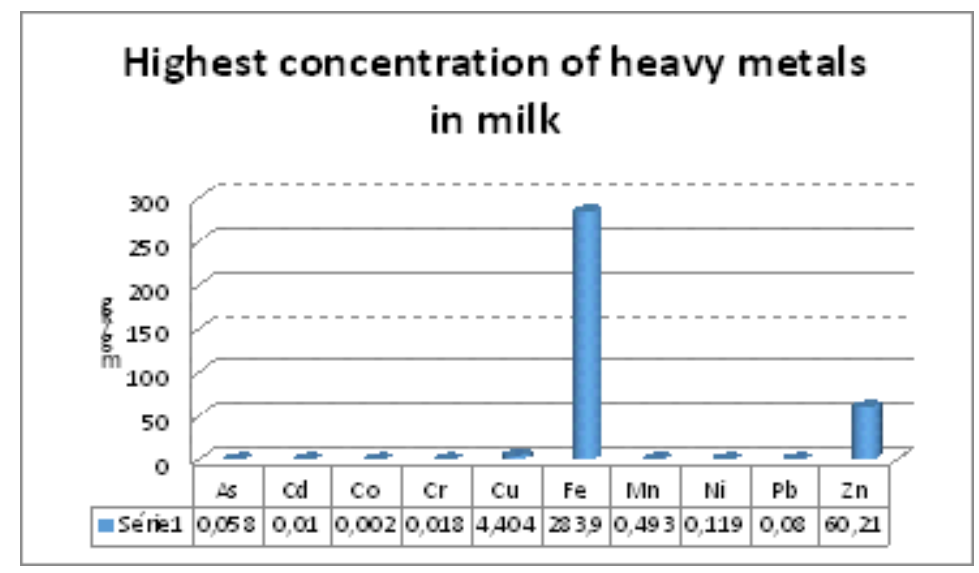

Figure 1. Heavy metals concentration in cow milk from three farms in Vojvodina district in Serbia. 


\section{DISCUSSION}

Milk as an essential source of nutrition for new born child and other mammals is bio active substance. Food contamination, especially heavy metals contamination of milk is considered as one of the most dangerous aspects [2]. The existence of trace elements and heavy metals in dairy products and milk has been recorded in various countries and regions $[4,15,16,19,21]$. Recommended maximum values of heavy metals in cow milk by IDF-International Dairy Federation [8] is $0.037 \mathrm{mg} / \mathrm{kg}$ for Fe, $0.328 \mathrm{mg} / \mathrm{kg}$ for $\mathrm{Zn}$ and $0.01 \mathrm{mg} / \mathrm{kg}$ for $\mathrm{Cu}$. Increased concentrations of heavy metals in body of domestic animals result in low fitness of animals, reproduction problems, immunity decline and occurrence of cancerous and teratogenic diseases [5]. $\mathrm{Cd}, \mathrm{Pb}$ and $\mathrm{Hg}$ persist in the body and exert their toxic effect by combining with one or more reactive groups essential for physiological functions of the cells thus causing cellular disturbances or clinical manifestation. The adverse toxic effects caused by $\mathrm{Pb}$, $\mathrm{Cd}, \mathrm{Hg}$ are widely recognized [9]. The major clinical signs in animals and humans for $\mathrm{Pb}$ and $\mathrm{Cu}$ poisoning are their direct effects on hematopoiesis, reduced integrity of red blood cells membrane leading to intravascular haemolysis, anemia and dehydration [18].

The presence of heavy metals in cow's milk may be attributed to contamination due to exposure of lactating cow to environmental pollution or consumption of contaminated feeding stuffs and water [6]. Therefore, determination of the heavy metals residual levels in milk could be indicator of the degree of pollution of the environment where the milk was produced [11].

Iron $(\mathrm{Fe})$ is a component of blood and many enzymes. It is involved in blood metabolism and oxygen transport. Milk contains a small amount of iron. The highest average values/concentration of $\mathrm{Fe}$ in cow milk it might be because cows were fed with hay from pasture rich in iron between April to May. Copper $(\mathrm{Cu})$ is a component of enzymes used in iron metabolism and it is found by Gakhar et al. [10] find that this heavy metal plays an important role in preventing mastitis in cows. Milk contains a small amount of copper. Some researchers found the amounts of $\mathrm{Cu}$ in the milk of individual varied from 0.2 to $0.8 \mathrm{mg} /$ $\mathrm{kg}$ [20]. Contrary to this findings, in current study the average values of $\mathrm{Cu}$ in cow milk was $4.404 \mathrm{mg} / \mathrm{kg}$. Malhat et al. [16] find the highest concentration of $\mathrm{Zn}$ in cow milk $(10.75 \mathrm{mg} / \mathrm{kg})$, lower compare to result in current study $(60.21 \mathrm{mg} / \mathrm{kg})$.

Arsenic (As) concentration was $0.058 \mathrm{mg} / \mathrm{kg}$, cadmium (Cd) was $0.01 \mathrm{mg} / \mathrm{kg}$, cobalt (Co) was 0.002 $\mathrm{mg} / \mathrm{kg}$, chrome (Cr) was $0.018 \mathrm{mg} / \mathrm{kg}$, manganese $(\mathrm{Mn})$ was $0.493 \mathrm{mg} / \mathrm{kg}$, nickel (Ni) was $0.119 \mathrm{mg} / \mathrm{kg}$ and lead $(\mathrm{Pb})$ was $0.08 \mathrm{mg} / \mathrm{kg}$ what is just above recommended values by International Dairy Federation [8].

\section{CONCLUSION}

In conclusion, results showed that most of the milk samples from the different farms are contained with all of the studied metals in concentration higher than those recommended by International Dairy Federation and Codex for cow milk. Therefore, it is important to note that the known concept of milk feeding of human infants with cow milk represents a possible lethal exposure route of heavy metal poisoning.

\section{MANUFACTURER}

${ }^{1}$ Termo Fisher Scientific Inc. Waltham, MA, USA.

Funding. This research was financed by the Ministry of Science and Technological Development, Republic of Serbia, Project IDP. No 31062.

Declaration of interest. The authors report no conflicts of interest. The authors alone are responsible for the content and writing of the paper.

\section{REFERENCES}

1 Anastasio A., Caggiano R., Macciato M., Paolo C., Ragosta M., Paino S. \& Cortesi M.L. 2006. Heavy metal concentrations in dairy products from sheep milk collected in two regions of southern Italy. Acta Veterinaria Scandinavica. 47: 69-74.

2 Ayana I., El Deen A.G. \& El-Metwally M. 2011. Behavior of certain lactic acid in the presence of pesticides residues. International Journal of Dairy Science. 6: 44-57.

3 Ayar A., Sert D. \& Akin N. 2009. The trace metal levels in milk and dairy products consumed in middle AnatoliaTurkey. Environmental Monitoring Assessment. 152: 1-12.

4 Bilandzic N. 2011. Trace element level from northern and southern refions of Croatia. Food Chemistry. 127(1): 63-66. 
5 Bires J., Dianovsky J., Bartko P. \& Juhasova Z. 1995. Effects on enzymes and the genetic apparatus of sheep after administration of samples from industrial emissions. Bio Metals. 8: 53-58.

6 Carl M. 1991. Heavy metals and other trace elements. Monograph on residues and contaminants in milk and milk products. International Dairy Federation "IDF", Special Issue. 9101: 112-119.

7 Codex Alimentarius Commission. 2007. Joint FAO/WHO food standard programme, Codex committee on methods of analysis and sampling 30th session (Rome, Italy). 81p.

8 IDF standard. 1979. Metal contamination in milk and milk products, International Dairy Federation Bulletin, Document No. A, Doe, 37.

9 Friberg L. \& Elinder C.G. 1988. Cadmium toxicity in humans. In: A.S. Prasad (Ed). Essential and toxic trace elements in human health and disease. New York: AR Liss, pp.559-587.

10 Gakhar G., Randhawa S.S., Randhawa C.S., Bansal B.K. \& Singh R.S. 2010. Effect of copper on the milk quality and prevention of mastitis in dairy cows. The Indian journal of animal sciences. 80(8): 727-728.

11 González-Montaña J.R., Senís E., Gutiérrez A. \& Prieto F. 2012. Environmental Monitoring and Assessment. 184: 4029-4034.

12 Houpert P., Mehennaoui S., Federspiel B., Kolf-Clauw M., Joseph-Enriquez B. \& Milhaud G. 1997. Transfer of cadmium from feed to ewe food products: variations in transfer induced by lead and zinc. Journal of Environmental Sciences. 5: 127-138.

13 Kazi T.G. 2009. Assessment of toxic metals in raw and processed milk samples using eletrothermal atomic absorption spectrophotometer. Food and Chemical Toxicology. 47(9): 2163-2169.

14 Li Y., McCrory D.F., Powel J.M., Saam H. \& Jackson-Smith D. 2005. A survey of selected heavy metal concentrations in Wisconsin Dairy Feeds. Journal Dairy Science. 88: 2911-2922.

15 Llobet J.M., Falco G., Casas C., Teixido A. \& Domingo J.L. 2003. Concentrations of Arsenic, Cadmium, Mercury and Lead in common foods and estimated daily Intake by children, adolescents, adult and seniors of Catalonia, Spain. Journal of Agricultural and Food Chemistry. 51: 838-842.

16 Malhat F., Hagag M., Saber A. \& Fayz A.E. 2012. Contamination of Cows Milk by Heavy Metal in Egypt. Bulletin Environmental Contamination and Toxicology. 88: 611-613.

17 Qin L.Q., Wang X.P., Li W., Tong X. \& Tong W.J. 2009. The minerals and heavy metals in cow's milk from China and Japan. Journal of Health Science. 55(2): 300-305.

18 Radostits O.M., Blood D.C. \& Gay C.C. 1994. Veterinary Medicine A Textbook of the Disease of Cattle, Sheep, Goat and Horses. 8th edn. London: Baillière Tindall, pp.1469-1499.

19 Rahimi E. 2013. Lead and cadmium concentrations in goat, cow, sheep and buffalo milks from different regions of Iran. Food chemistry. 136(2): 389-391.

20 Supplee G.C. \& Bellis B. 1922. The copper content of cow`s milk. Journal of Dairy Sciences. 5(5): 455-467.

21 Tripathi R. 1999. Daily intake of heavy metals by infants through milk and milk products. Science of the total environment. 227(2): 611-613. 